\title{
Cytopathologic evaluation of patients submitted to radiotherapy for uterine cervix cancer
}

\author{
Cátia Martins Leite Padilha ${ }^{1 *}$, Mário Lúcio Cordeiro Araújo Junior², Sergio Augusto Lopes de Souzaª \\ ${ }^{1} \mathrm{MSC}$ in Pathology from Universidade Federal Fluminense (UFF). Staff (Cytopathology), Instituto Nacional de Câncer (Inca), Rio de Janeiro, RJ, Brazil \\ ${ }^{2} \mathrm{PhD}$ in Medical Sciences from Universidade do Estado do Rio de Janeiro (Ueri). MD, Anatomic Pathologist, and Vice-director (HC2) of INCA, Rio de Janeiro, RJ, Brazi \\ 3Postdoctoral Fellowship from Universidade Federal do Rio de Janeiro (UFRJ). Adjunct Professor, Faculdade de Medicina da Universidade Federal do Rio de Janeiro (FM-UFRJ), Rio de Janeiro, RJ, Brazil
}

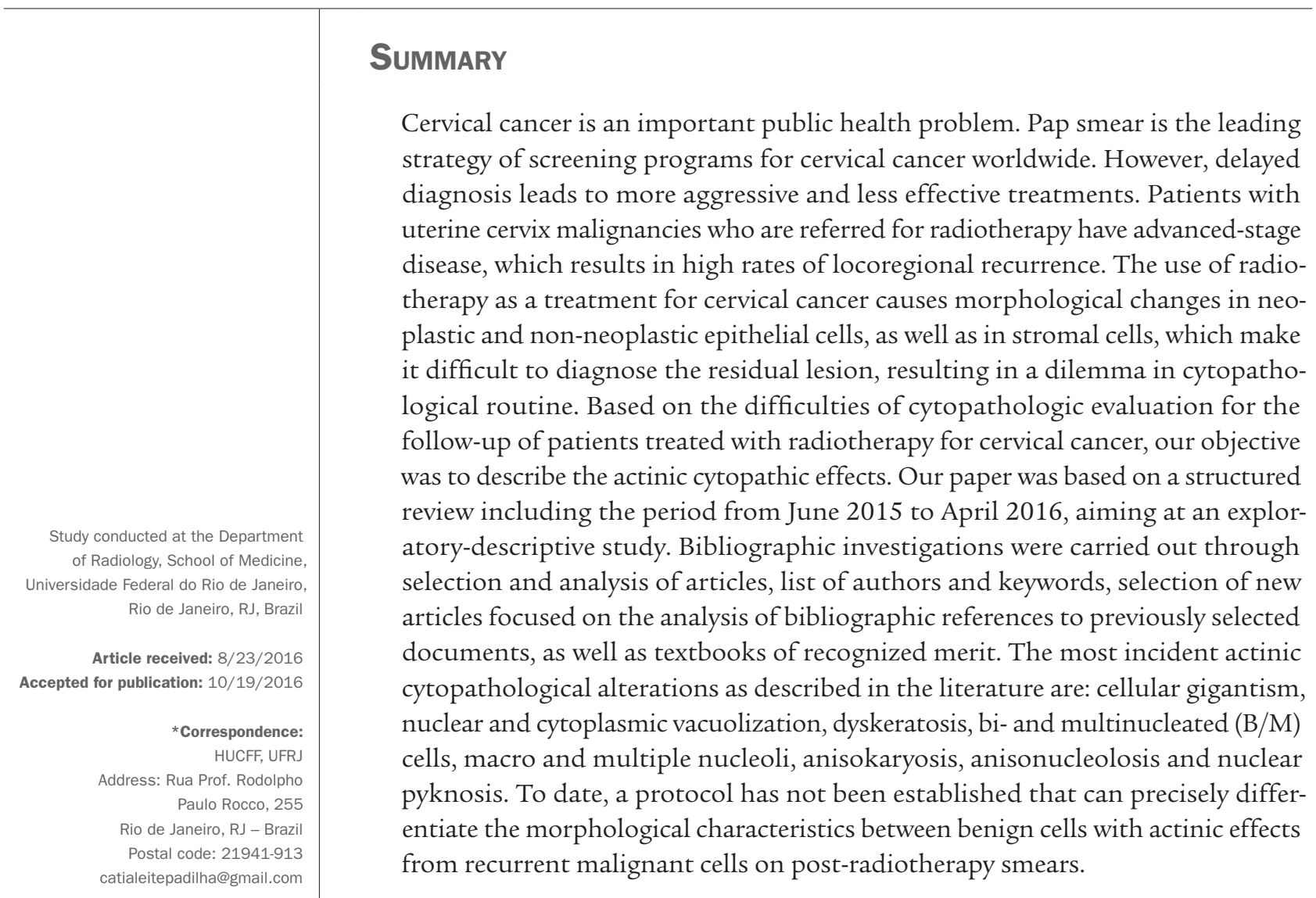

Keywords: radiotherapy, uterine cervix neoplasms, actinic effects, cytopathology.

\section{INTRODUCTION}

Cervical cancer is an important public health problem worldwide. Its incidence is higher in less developed countries, compared to the more developed ones. ${ }^{1}$ The disease usually begins after the age of 30 years, and its risk increases quickly until it reaches a peak between the ages of 50 and 60 years. According to Instituto Nacional de Câncer (Inca, in the Portuguese acronym), 16,340 new cases of cervical cancer were expected in Brazil in 2016, with an estimated risk of 15.85 cases per 100,000 women. In the Northern Region, for example, this malignant tumor is the most incident among the female population. ${ }^{1}$

Pap smear (Papanicolaou) is the leading strategy of screening programs for cervical cancer worldwide. In Brazil, the strategy recommended by the Ministry of Health is cytopathological examination in women aged 25 to 64 years. For an effective cervical cancer control program, the organization, integrity and quality of services and actions in the care chain must be guaranteed, as much as patient treatment and follow-up. ${ }^{2,3}$ Pap smears are considered highly effective, low-cost, and are well accepted by the population. ${ }^{4}$

Delays in diagnosis, on the contrary, lead to more aggressive and less effective treatments, in addition to raising hospitalization costs and mortality rates. As an example, a large proportion of Brazilian women do not regularly undergo cervical cancer screening due to shyness, fear, or lack of awareness, and are thus excluded from prevention and detection measures. ${ }^{4}$ 
Patients with uterine cervix malignancies who are referred for radiotherapy have advanced-stage disease, which results in high rates of locoregional recurrence. ${ }^{5}$ In cases of cervical cancer, cytopathological examination should be performed to control possible residual neoplasm or recurrence of neoplasm after radiotherapy. ${ }^{2,6,7}$

Follow-up of cervical cancer patients treated with curative intent is based on the premise that early detection of a recurrence would result in decreased morbidity and mortality from this disease. Currently, follow-up protocols vary widely, especially in relation to the number of tests and intervals. There are no formal recommendations for an ideal program to monitor these patients. However, the importance of performing periodic exams (physical, cytopathological, colposcopic and imaging) is a consensus. ${ }^{2,3,8}$

According to the handbook of gynecologic oncology practice by Hospital A.C. Camargo (Manual de condutas em ginecologia oncológica, 2010), clinical and colpocytological reevaluations every 3-4 months in the first 2 years, with intervals of 6 months from the third to the fifth year of follow-up and annual return after 5 years, are recommended for follow-up of patients irradiated due to cervical cancer, in addition to individualized imaging tests. ${ }^{8}$

The use of radiotherapy as a treatment for cervical cancer causes morphological changes in neoplastic and nonneoplastic epithelial cells, as well as in stromal cells. These alterations make it difficult to diagnose the residual lesion, resulting in a dilemma in cytopathological routine. ${ }^{9}$ Actinic cellular atypia may produce false-positive results, but also false-negatives, given the difficulty in collecting adequate samples due to changes in the anatomy of the cervix and vaginal canal, mainly caused by brachytherapy. ${ }^{10}$ Subjectivity in the interpretation of changes is also a limitation of the method. ${ }^{2}$

Based on the difficulties of cytopathologic evaluation for the follow-up of patients treated with radiotherapy for cervical cancer, our objective was to describe actinic cytopathic effects in the follow-up of patients with cervical cancer after radiotherapy.

\section{Method}

This paper was based on a structured review that included the interval from June 2015 to April 2016, and followed the methods proposed by Villas et al. ${ }^{11}$ and Mendes et al., ${ }^{12}$ aiming at an exploratory-descriptive study. Bibliographic investigations were carried out through selection and analysis of articles, list of authors and keywords, selection of new articles focused on the analysis of bibliographic references to previously selected documents, as well as textbooks of recognized merit. The main purpose of exploratory-descriptive studies is to characterize aspects of a given research object compared to previously accumulated knowledge. They are particularly suitable because the object of study is not recurrent in the literature. ${ }^{13}$ Data collection included journals indexed in the following databases: MedLine, LILACS, PsycINFO, SciELO Brasil, and the CAPES Portal: http://periodicos.capes.gov.br. There was no time limitation, but articles published between 2005 and 2016 were prioritized.

\section{Theoretical BASIS}

Conceptually, ionizing radiation consists of electromagnetic waves with enough energy to cause electrons to detach from atoms and molecules, changing their structure in a process known as ionization. As a result, they become electrically charged. There are several types of ionizing radiation and each has different penetration power, causing different degrees of ionization in matter. ${ }^{14,15}$ Ionizing radiation penetrates according to its type and energy. While alpha particles can be blocked by a sheet of paper, beta particles require a few millimeters of a material such as aluminum, to block them, while high-energy gamma radiation requires dense materials to block it, such as lead or concrete..$^{14,15}$

Ionizing radiation can occur naturally, for example, by the decomposition of natural radioactive substances such as radon gas. The rate at which a radionuclide decomposes (becomes less radioactive) is called half-life, which is the time it takes for a radioactive material to reduce its activity by half. Depending on the radionuclide, this can range from fractions of a second to millions of years. It is possible to measure radiation in various materials, even at very low levels, and the amount of measured radioactivity is expressed as a concentration..$^{14,15}$

\section{Biological EFFECTS OF RADIATION}

Ionizing radiation interacts with living matter in a process that takes place at the atomic level. Biological molecules are mainly constituted by atoms of carbon, hydrogen, oxygen and nitrogen that can be ejected when irradiated. The transformation of a macromolecule by the action of radiation promotes harmful consequences that can be observed in the cells. Likewise, the generation of new chemical entities in the system also has an impact on the irradiated cell. On the other hand, water molecules are the most abundant in the human body, with about $2 \times 10^{25}$ molecules of water per kilogram, allowing us to state that, in case of exposure to radiation, the molecules affected in greater numbers will be those of water that suffer ra- 
diolysis. After ionization, the water molecules undergo an electronic rearrangement with the possibility of producing free radicals due to the presence of atoms whose last layer does not have the number of electrons that would give stability to the structure. ${ }^{15-18}$

DNA is a macromolecule responsible for encoding the molecular structure of all cellular enzymes, and it is key to the process of establishing biological damage. By undergoing direct (ionizing) or indirect (through free radical attack) radiation action, DNA is exposed to basically two types of damage: gene mutation and lysis. ${ }^{16-19}$

DNA lesions are the most biologically important because they can compromise vital processes such as cell replication and transcription. ${ }^{20}$ The different lesions produced by radiation, if left unrepaired, can compromise important biological functions such as DNA transcription and replication, leading to cell death. Failure to repair damage leads to mutagenesis when they are present in the DNA during replication. ${ }^{21}$

The distribution and repair of lesions caused in DNA depend on the nucleotide sequence, whether or not they are in transcribed regions, and the accessibility to DNA by its association with chromosomal proteins. ${ }^{22}$ Despite the ability of human cells to remove nucleotides damaged by radiation by means of excision mechanisms, some lesions remain in the genome. Radiation-induced carcinogenesis involves the inactivation of one or more tumor suppressor genes or the activation of pro-oncogenes. The disease can also result from a gene product altered by a mutation. ${ }^{22}$

\section{RADIOTHERAPY}

Radiotherapy is a method capable of destroying tumor cells by employing a beam of ionizing radiation. A precalculated dose of radiation is applied at a given time to a volume of tissue encompassing the tumor, seeking to eradicate all tumor cells with the least possible damage to the surrounding normal cells, which play a vital role in the regeneration of the irradiated area. Ionizing radiation is electromagnetic or corpuscular in nature and carries energy. By interacting with the tissues, they produce fast electrons that ionize the medium and create chemical effects such as water hydrolysis and the breakdown of DNA strands. Cell death can then occur through a variety of mechanisms, from the inactivation of systems that are vital for the cell to its inability to reproduce. Tissue response to radiation depends on many factors, such as tumor sensitivity to radiation, location and oxygenation, as well as the quality and amount of radiation, and the total time it is administered. In order for the biological effect to reach a greater number of neoplastic cells and tolerance of normal tissues to be respected, the total dose of radiation administered is usually fractionated in equal daily doses when external therapy is used., ${ }^{3,23}$

The rate of tumor regression represents the degree of sensitivity of the tumor to radiation. It depends fundamentally on its cellular origin, its degree of differentiation, oxygenation and the clinical presentation. Most radiosensitive tumors are radiocurable. However, some tumors spread despite local control and others have their sensitivity so close to that of normal tissues that it is not possible to apply the eradication dose. Local curability is only achieved when the dose of radiation applied is lethal to all tumor cells, but does not exceed the tolerance of normal tissues. ${ }^{3,23}$

Radiotherapy is used in approximately $60 \%$ of all diagnosed cases of malignant tumors, including those most prevalent in Brazil, namely prostate, lung, breast and cervical cancers. This means that, out of every 100 patients, 60 will undergo radiotherapy in one of their evolutionary stages. ${ }^{19,23}$ In recent times, the most significant development in the treatment of locally advanced cervical carcinoma has been the introduction of radiochemotherapy. However, there are some impediments to its administration, including elderly patients, patients with pre-existing diseases and patients who refuse chemotherapy. There are also financial issues, such as the cost of chemotherapy and the cost of managing toxicities. ${ }^{19}$

\section{Cervical cancer}

Squamous or epidermoid carcinoma accounts for more than $80 \%$ of malignant cervical neoplasms. Adenocarcinoma (endocervical adenocarcinoma, endometrioid, clear cells, adenocystic, adenosquamous) is a less frequent type that affects the glandular epithelium and corresponds to about $10 \%$ of the cases. ${ }^{1,8}$ Other histopathological types that appear less frequently are sarcomas (embryonal rhabdomyosarcoma [children] and leiomyosarcoma), melanoma, small cell carcinoma (neuroendocrine), and metastatic carcinoma. ${ }^{8,24}$

The main risk factor for the development of cervical cancer is persistent infection with human papillomavirus (HPV) associated with cofactors, especially immunosuppression and smoking. The mean age of women with this diagnosis is 51.4 years. Squamous carcinoma progresses from precursor stages, the so-called intraepithelial lesions. Low-grade lesions may progress over time to high-grade lesions. Then, neoplastic cells can rupture the basement membrane and invade the underlying stroma. However, some tumors do not appear to start as low-grade lesions, evolving from high-grade lesions from the beginning. ${ }^{7,25}$ 
Microinvasive carcinoma represents the initial stage of stromal infiltration by neoplastic cells that ruptured the basement membrane, measuring up to $5 \mathrm{~mm}$ deep and $7 \mathrm{~mm}$ wide in the underlying cervical stroma. However, it is only diagnosed microscopically. ${ }^{8,25-27}$ From the practical point of view, it is impossible in smears to accurately ensure that a carcinoma lesion is microinvasive. The cytological pattern may resemble a high-grade squamous intraepithelial lesion or an invasive carcinoma. The category of high-grade squamous intraepithelial lesion with suspected invasion characteristics (Bethesda System) or high-grade intraepithelial lesion, which cannot rule out microinvasion (Brazilian Nomenclature for Cervical Reports), can be applied when neoplastic cells in syncytial clusters exhibit occasional nucleoli and parachromatin clearing. Frankly invasive squamous carcinoma shows in histopathological examination nests of neoplastic cells infiltrating the stroma beyond $5 \mathrm{~mm}$ depth from the basement membrane..$^{25-27}$

\section{Differential diagnoses of Cervical CANCER}

In cervical neoplasms, differential diagnoses are essentially made by a process of elimination. ${ }^{26,27}$ The most common include:

- Squamous intraepithelial lesions, especially keratinizing ones (absence of tumor diathesis, absence of "clear spaces" in nuclei characterizing the irregular distribution of chromatin, absence of nucleolus in other non-keratinized abnormal cells).

- Repair process (rare isolated cells, lower nuclear-cytoplasmic ratio, less significant abnormalities in chromatin distribution, absence of tumor diathesis).

- Atrophy (absence of irregularity in nuclear margins, absence of irregularities in chromatin distribution).

- Cytopathic changes by herpes virus (multinucleation, nuclear molding and chromatin rarefaction in other cells).

- Effect of radiotherapy/chemotherapy (macrocytosis, polychromasia, cytoplasmic vacuolization, chromatin with "blurred" appearance).

- Poorly differentiated endocervical or endometrial adenocarcinoma (glandular arrangements and spherical arrangements, columnar cells in endocervical adenocarcinoma, frequent vacuolation and common neutrophil infiltration in endometrial adenocarcinoma, sometimes eccentric nuclei, with less hyperchromasia and more frequent and prominent nucleoli, absence of keratinized cells).

- Metastatic adenocarcinoma (characteristics similar to those described above). ${ }^{26-29}$

\section{Post-Radiotherapy efFects ON CELlS}

Cellular and molecular changes induced by radiotherapy include: nuclear DNA destruction or damage, inhibition of protein synthesis, and denaturation/coagulation of proteins. Normal cells are also compromised, resulting in their death or in nuclear and cytoplasmic changes that may persist for many years. ${ }^{19,29,32,33}$ Cervical smear is considered an excellent method of investigation in the follow-up of patients undergoing radiation therapy for cervical cancer. The finding of malignant cells that persist after treatment or that reappear soon after allows immediate clinical and/or surgical intervention before the onset of any symptoms. It is important to note that after the beginning of radiotherapy, during a period between four and eight weeks, cervical smears will show abundant necrotic material, with many inflammatory cells and occasional malignant cells. Cytological examination, therefore, is not indicated at this stage to assess whether the neoplasm persists. After this period, all malignant cells disappear, and an atrophic cytological pattern is established. ${ }^{19,27,29,32,33}$ Cellular changes are related to both the acute and to the chronic phases following radiation therapy. It is not always easy to differentiate these changes from those of malignant cells. On the other hand, a cytopathologist with little experience in this area may underestimate the changes, missing the opportunity to detect early or recurrent cancer. ${ }^{19,29-31}$

Persistent or recurrent carcinoma is diagnosed in the cervicovaginal smear when malignant cells are identified in the course of radiotherapy or immediately after its completion. It indicates radioresistance of the neoplastic cells, being thus related to a poorer prognosis. Persistent malignant cells exhibit, in addition to irradiation-related alterations, others that are associated with malignancy. Thus, in addition to pleomorphism and hyperchromasia that are common in cells affected by irradiation, there is thickening of the nuclear margins and a well-preserved, coarse and irregularly distributed chromatin. Increased nuclear-cytoplasmic ratio is also observed. The presence of keratinized, pleomorphic cells may indicate malignancy. The most reliable criterion to establish the viability of neoplastic cells is the finding of mitoses. ${ }^{26,27,34}$

Since radiotherapy is associated with characteristic cytological changes, including nuclear activation, increased cytoplasm (with preservation of the nuclear-cytoplasmic ratio), cytoplasmic vacuolization, eosinophilia, polychromasia, multinucleated giant cells, nuclear membrane blebbing and nuclear vacuolization, as well as repair cells, atypical stromal cells, endothelial cells and macrophages, ${ }^{29,31,35}$ cytological samples should be collected a few months after radiotherapy. However, it is 
true that radiotherapy is associated with unsatisfactory samples. According to Wright et al., ${ }^{33}$ liquid-based cytology considerably reduced the occurrence of unsatisfactory results in the studies performed by them, with only $2.7 \%$ of the cytopathological exams (8 of 294) being described as unsatisfactory. They concluded that the use of ThinPrep to perform post-irradiation Pap smears is associated with a high satisfactory cytology rate. Other studies using the SurePath method also corroborated these results. ${ }^{29,31,36-41}$ However, the method is still too expensive to be used applied on a large scale. ${ }^{29}$

Cells with actinic effects may be confused with dyskaryotic atypia and produce false-positive results. False-negatives may also occur as a result of actinic changes, as well as difficulty in collecting adequate samples because of changes in the anatomy of the cervix and vaginal canal, especially with brachytherapy, leading to inadequate treatment. It is a consensus among professionals who perform microscopic analyzes (cytopathologists, cytologists and cytotechnicians) ${ }^{42}$ that it is often difficult to differentiate actinic alterations in normal cells from cellular atypia in recurrent tumors. ${ }^{2}$

\section{Results}

\section{Post-radiotherapy cytopathologic diagnosis}

Several methods have already been used to test the radiosensitivity of cervical cancer. Some measure the tumor response and others measure host response, such as the cytopathologic method. ${ }^{43}$ The quantitative and qualitative analysis of SR-sensitive and RR-resistant cells, as described by Graham, ${ }^{44}$ served as a parameter for post-radiotherapy diagnosis for a long time, but today it is no longer used in most services. ${ }^{2,9,34}$ Several authors have didactically classified cytological changes caused by radiation as immediate or chronic, delimited in annual periods, ${ }^{34,45}$ or acute, intermediate or chronic. ${ }^{9}$

Although the morphology generates difficulties to define all the cytological changes induced by radiation, it is still considered by several authors an effective means of post-therapeutic control. ${ }^{45,46}$ In order to improve cytological diagnosis, methods such as computerized cytometry, specific immunoreactions, immunocytochemistry, and other techniques have been used. However, to date there is no effective protocol to predict the biological behavior of some cell types found in post-radiotherapy smears. ${ }^{45-48}$

\section{Post-radiotherapy cytopathologic criteria}

In general, almost all cells undergo radiation-induced changes. ${ }^{45}$ Cellular alterations, despite the previously mentioned pattern, can display, depending on gravity, a wide and complex series of morphological modifications, with the appearance of bizarre cytological formations that are difficult to interpret. ${ }^{49}$ Table 1 shows the main cytological findings in post-radiotherapy smears. ${ }^{2,934,43-49}$

\begin{tabular}{l} 
TABLE 1 Main cytological findings induced by radiation \\
in cervicovaginal smears. \\
Increased cytoplasm \\
\hline Cytoplasmic vacuolization \\
\hline Cytoplasmic degeneration \\
\hline Cytoplasmic pallor \\
\hline Cellular atrophy \\
\hline Cellular gigantism \\
\hline Amphophilia \\
\hline Dyskeratosis \\
\hline Pleomorphism \\
\hline Nuclear increase (without compromising the nuclear-cytoplasmic \\
ratio) \\
\hline Nuclear vacuolization \\
\hline Nuclear degeneration \\
\hline Nuclear pallor \\
\hline Hyperchromasia \\
\hline Dyskaryosis (present in malignant cells) \\
\hline Mitosis (typical or atypical) \\
\hline Binucleation \\
\hline Multinucleation \\
\hline Karyorrhexis \\
\hline Nuclear pyknosis \\
\hline Anisokaryosis \\
\hline Necrosis \\
\hline Leukocyte infiltrate \\
\hline Multinucleated giant cells \\
\hline Repair cells \\
\hline Macro and multiple nucleoli \\
\hline Anisonucleolosis \\
\hline
\end{tabular}

\section{Conclusion}

To date, a protocol has not been established to precisely differentiate the morphological characteristics of benign cells with actinic effects from recurrent malignant cells on post-radiotherapy smears. However, there are several studies aimed at minimizing occasional diagnostic difficulties. The information presented here allows for a critical and reflexive analysis of the knowledge about the impact of radiotherapy on epithelial cells, allowing us to point out difficulties, limitations and potentialities that affect the medical practice and the care provided during cytopathological follow-up of patients submitted to cervical cancer radiotherapy.

The most incident actinic cytopathological alterations as described in the literature are: cellular gigantism, nuclear 
and cytoplasmic vacuolization, dyskeratosis, bi- and multinucleated (B/M) cells, macro and multiple nucleoli, anisokaryosis, anisonucleolosis and nuclear pyknosis (Figure 1).

The difficulties pointed out show the importance of considering in future studies the experience of the professionals involved in the analysis of irradiated cells and a reflection on the subjectivity of the method. In general, our review provided insights to help coordinate further training for professionals dedicated to the analysis and diagnosis of cells under actinic effects, in addition to recommending complementary studies using techniques that contribute to the understanding of actinic alterations in order to increase prognostic acuity.

\section{Resumo}

Avaliação citopatológica no seguimento de pacientes submetidas à radioterapia por câncer de colo uterino

O câncer de colo uterino configura-se como um importante problema de saúde pública. O teste citopatológico é a principal estratégia de programas de rastreamento dessa neoplasia maligna em todo o mundo. Entretanto, a demora no diagnóstico ocasiona tratamentos mais agressivos e menos efetivos. Pacientes com neoplasia maligna de colo uterino que são encaminhadas para radioterapia apresen- tam doença em estádios avançados, e esse fato determina altos índices de recidiva locorregional. A utilização da radioterapia como tratamento do câncer do colo uterino provoca alterações morfológicas não só nas células epiteliais neoplásicas e não neoplásicas como também nas células estromais, o que dificulta o diagnóstico da lesão residual e resulta em um dilema na rotina citopatológica. Com base nas dificuldades da avaliação citopatológica do seguimento das pacientes pós-radioterapia, o objetivo deste trabalho foi descrever os efeitos citopáticos actínicos. O trabalho teve como base uma revisão estruturada no período de junho de 2015 a abril de 2016, visando a um estudo exploratório-descritivo. As investigações bibliográficas foram realizadas por meio de seleção e análise dos artigos, lista de autores e palavras-chave; seleção de novos artigos focada na análise de referências bibliográficas dos documentos previamente selecionados e livros-texto de relevância conceitual. As alterações citopatológicas actínicas mais incidentes descritas na literatura são: gigantismo celular, vacuolização nuclear e citoplasmática, disceratose, bi e multinucleações, macro e múltiplos nucléolos, anisocariose, anisonucleolose e picnose nuclear. Até o momento, não se conseguiu estabelecer um protocolo que possa diferenciar precisamente as características morfológicas entre células benignas com efeitos actínicos das células malignas recidivantes em esfregaços pós-radioterapia.

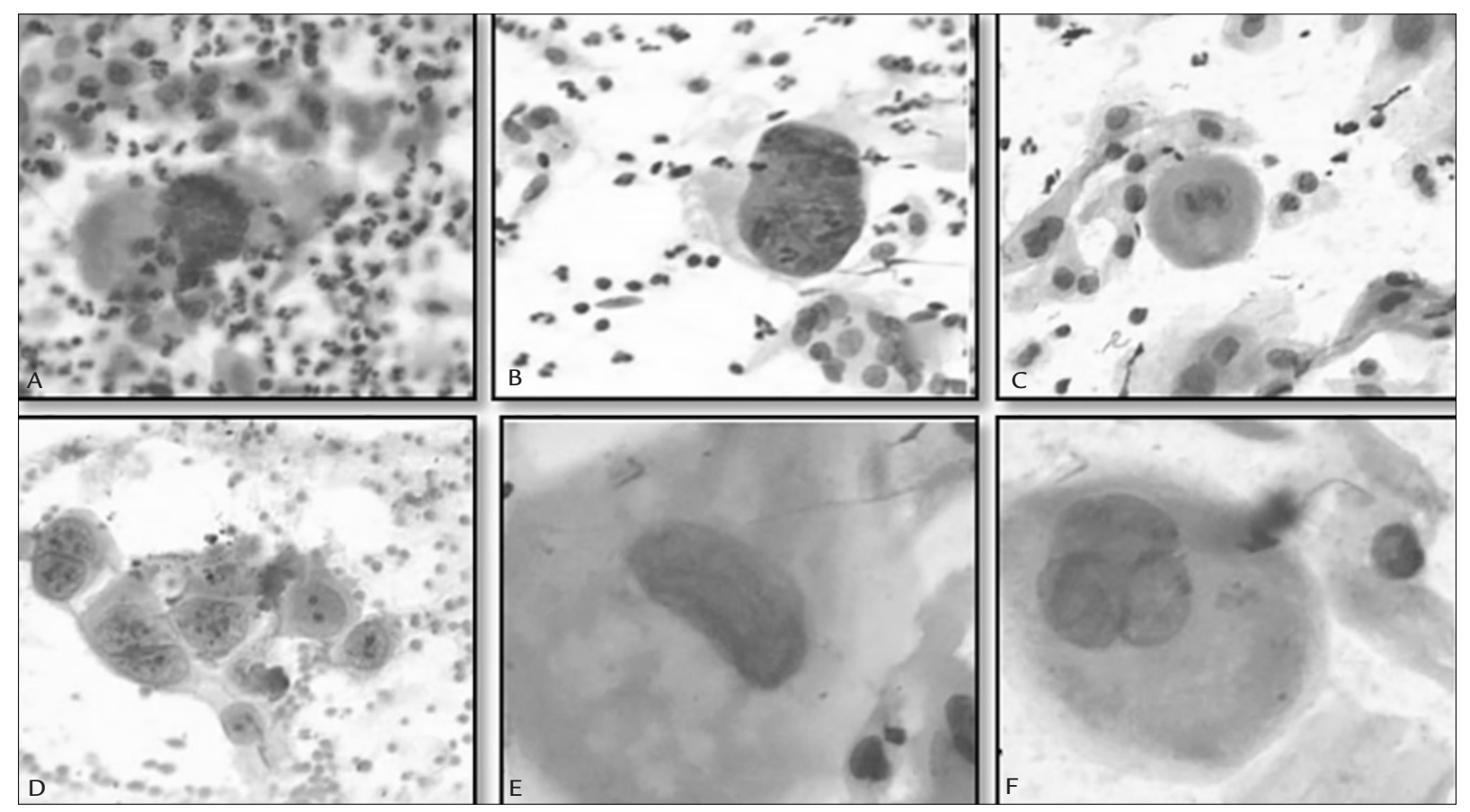

FIGURE 1 Actinic cytopathological aspects. Source: Padilha et al. ${ }^{2}$ 
Palavras-chave: radioterapia, neoplasias do colo do útero, efeitos actínicos, citopatologia.

\section{References}

1. Instituto Nacional de Câncer - INCA. Radioterapia [cited 2016 May]. Available from: http://www.inca.gov.br/conteudo_view.asp?ID=100.

2. Padilha CML, Feliciano GD, Padilha Filho LG. Analysis of actinic effect after radiotherapy in the uterine cervix carcinomas. J Am Sci. 2006; 2(3):23-28.

3. Instituto Nacional de Câncer José Alencar Gomes da Silva / INCA. Estimativa 2016: Incidência de Câncer no Brasil / Instituto Nacional de Câncer José Alencar Gomes da Silva. Coordenação de Prevenção e Vigilância. Rio de Janeiro: INCA; 2014.

4. Panobianco MS, Pimentel AV, Almeida AM, Oliveira ISB. Women diagnosed with advanced cancer of the cervix: coping with the disease and treatment. Rev Bras Cancerol. 2012; 58(3):517-23.

5. Yuan G, Wu L, Huang M, Li N, An J. A phase II study of concurrent chemoradiotherapy with weekly nedaplatin in advanced squamous cell carcinoma of the uterine cervix. Radiation Oncol. 2014; 9:55.

6. Solomon D, Davey D, Kurman R, Moriarty A, O'Connor D, Prey M, et al.; Forum Group Members; Bethesda 2001 Workshop. The 2001 Bethesda System: terminology for reporting results of cervical cytology. JAMA. 2002; 287(16):2114-9

7. Ministério da Saúde. Instituto Nacional de Câncer José Alencar Gomes da Silva / INCA. Nomenclatura Brasileira para Laudos Citopatológicos Cervicais. Coordenação-Geral de Prevenção e Vigilância, Divisão de Detecção Precoce e Apoio à Organização de Rede. 3. ed. Rio de Janeiro: Inca; 2012.

8. Hospital AC Camargo. Manual de condutas em ginecologia oncológica. São Paulo: FAP; 2010

9. Powers CN. Radiation treatment effects in cervical cytology. Diagn Cytopathol. 1995; 13(1):75-80

10. Zannoni GF, Velone GV, Carbone A. Morphological effects of radiochemotherapy on cervical carcinoma: a morphological study of 50 cases of hysterectomy specimens after neoadjuvant treatment. Int J Gynecol Pathol. 2008; 27(2):274-81.

11. Villas MV, Macedo-Soares TDLVA, Russo GM. Bibliographical research method for business administration studies: a model based on scientific journal ranking. Braz Admin Rev. 2008; 5(2):139-59.

12. Mendes KDS, Silveira RCCP, Galvão CM. Revisão integrativa: método de pesquisa para a incorporação de evidências na saúde e na enfermagem. Texto \& Contexto Enferm. 2008; 17(4):758-64.

13. Gil AC. Como delinear uma pesquisa bibliográfica. In: Gil AC, organizer. Como elaborar projeto de pesquisa. 4. ed. São Paulo: Atlas; 2002

14. Okuno E. Efeitos biológicos das radiações ionizantes. Acidente radiológico de Goiânia. Estud Av. 2013; 27(77):185-99.

15. Okuno E. Radiação: efeitos, riscos e benefícios. São Paulo: Harbra; 1988.

16. Vargas FG, Silva BS, Cardoso CO, Leguisamo N, Moraes CAR, Moraes CV, et al. Impact of body weight on radiation exposure during invasive cardiac procedures. Rev Bras Cardiol Invasiva. 2012; 20(1):63-8.

17. Souza E, Soares JPM. Correlações técnicas e ocupacionais da radiologia intervencionista. J Vasc Bras (Porto Alegre). 2008; 7(4):341-50.

18. Ribeiro EL, Pessoa MB. The effects of electromagnetic radiation in the life of the human being: An analysis of the environmental paradigm. Rev Tecnologia e Sociedade. 2007. Available from: https://periodicos.utfpr.edu. $\mathrm{br} / \mathrm{rts} /$ article/download/2502/1616.

19. Sharma M, Revannasiddaiah S, Gupta M, Seam RK, Gupta Mk, Rastogi M. Can pure accelerated radiotherapy given as six fractions weekly be an option in locally advanced carcinoma cervix: results of a prospective randomized phase III trial. J Can Res Ther. 2016; 12(1):103-8.

20. Friedberg EC, Walker GC, Siede W, Wood, RD, Schultz RA, Ellenberger T. DNA repair and mutagenesis. Washington: ASM Press; 2006

21. Choi JH, Besaratina A, Lee DH, Lee CS, Pfeifer GP. The role of DNA polymerase iota in UV mutational spectra. Mutat Res. 2006; 599(1-2):58-65.

22. Matsumura $Y$, Ananthaswamy $\mathrm{H}$. Toxic effects of ultraviolet radiation on the skin. Toxicol Appl Pharmacol. 2004; 195(3):298-308.

23. Mundt AJ, Lujan AE, Rotmensch J, Waggoner SE, Yamada SD, Fleming G, et al. Intensity-modulated whole pelvic radiotherapy in women with gynecologic malignancies. Int J Radiat Oncol Biol Phys. 2002; 52(5):1330-7.

24. INCA/MS. Câncer do colo do útero. Rev Bras Cancerol. 2000; 46(4):351-4.
25. Castle PE, Schiffman M, Wheeler CM. Hybrid capture 2 viral load and the 2-year cumulative risk of cervical intraepithelial neoplasia grade 3 or cancer. Am J Obstet Gynecol. 2004; 191(5):1590-7.

26. Navarro C, Fonseca AJ, Sibajev A, Souza CIA, Araújo DS, Teles DA, et al. Cervical cancer screening coverage in a high-incidence region. Rev Saúde Pública. 2015; 49:17.

27. Solomon D, Nayar R. The Bethesda System for reporting cervical cytology: definitions, criteria, and explanatory notes. 2. ed. New York: Springer; 2004

28. Pinto AP, Maia R. [Adenosquamous carcinoma of the cervix mimicking adenoid basal carcinoma: case report and review of the literature]. J Bras Patol Med Lab. 2007; 43(1):45-50.

29. Costa MOLP, Heráclio AS, Coelho AV, Acioly VL, Souza PR, Correia MT. Comparison of conventional Papanicolaou cytology samples with liquid-based cervical cytology samples from women in Pernambuco, Brazil. Braz J Med Biol Res. 2015; 48(9):831-8.

30. Mcgoogan E, Colgan TJ, Ramzy I, Cochand-Priollet B, Davey DD, Grohs HK, et al. Cell preparation methods and criteria for sample adequacy. International Academy of Cytology Task Force summary. Diagnostic Cytology Towards the 21st Century: An International Expert Conference and Tutorial. Acta Cytol. 1998; 42(1):25-32.

31. Lu CH, Chang CC, Ho ESC, Chen SJ, Lin SJ, Fu TF, et al. Should adequacy criteria in cervicovaginal cytology be modified after radiotherapy, chemotherapy, or hysterectomy? Cancer Cytopathol. 2010; 118(6):474-81.

32. Zannoni GF, Velone GV. Accuracy of Papanicolaou smears in cervical cancer patients treated with radiochemotherapy followed by radical surgery. Am J Clin Pathol. 2008; 130(5):787-94.

33. Wright JD, Herzog TJ, Mutch DG, Gibb RK, Rader JS, Davila RM, et al. Liquid-based cytology for the postirradiation surveillance of women with gynecologic malignancies. Gynecol Oncol. 2003; 91(1):134-8

34. Gupta S, Mukherjee K, Gupta YN, Kumar M. Sequential radiation changes in cytology of vaginal smears in carcinoma of cervix uteri during radiotherapy. Int J Gynaecol Obstet. 1987; 25(4):303-8.

35. Shield PW. Chronic radiation effects: a correlative study of smears and biopsies from the cervix and vagina. Diagn Cytophatol.1995; 13(2):107-19.

36. Alsharif M, McKeon DM, Gulbahce HE, Savik K, Pambuccian SE. Unsatisfactory surepath liquid-based Papanicolaou tests: causes and significance. Cancer. 2009; 117(1):15-26.

37. Baker JJ. Conventional and liquid-based cervicovaginal cytology: a comparison study with clinical and histologic follow-up. Diagn Cytopathol. 2002; 27(3):185-8.

38. Bolick DR, Hellman DJ. Laboratory implementation and efficacy assessment of the ThinPrep cervical cancer screening system. Acta Cytol. 1998; 42(1):209-13.

39. Bur M, Knowles K, Pekow P, Corral O, Donovan J. Comparison of ThinPrep preparations with conventional cervicovaginal smears. Practical considerations. Acta Cytol. 1995; 39(4):631-42.

40. Carpenter AB, Davey DD. ThinPrep Pap Test: performance and biopsy follow-up in a university hospital. Cancer. 1999; 87(3):105-12.

41. Linder J, Zahniser D. The ThinPrep Pap Test. A review of clinical studies. Acta Cytol. 1997; 41(1):30-8.

42. Teixeira LA, Porto MAT, Souza LPA. A expansão do rastreio do câncer do colo do útero e a formação de citotécnicos no Brasil. Physis (Rio J). 2012; 22(2):713-31.

43. Gusberg SB. A consideration of the problem of radiosensitivity in cancer of the cervix. Am J Obstet Gynecol. 1956; 72(4):804-19.

44. Graham JB, Graham RM, Liu W. Prognosis in cancer of the uterine cervix based on the vaginal smear before treatment; SR: the sensitization response. Surg Gynecol Obstet. 1954; 99(5):11

45. Murad TM, August C. Radiation-induced atypia. A rewiew. Diagn Cytopathol. 1985; 1(2):135-52.

46. Shield PW, Wrigth RG, Free K, Daunter B. The accuracy of cervicovaginal cytology in the detection of recurrent cervical carcinoma following radiotherapy. Gynecol Oncol. 1995; 41(3):223-9.

47. Davey DD, Gallion H, Jennings CD. DNA cytometry in postirradiation cervico-vaginal smear. Hum Pathol. 1992; 23(9):1027-31.

48. Wacthel MS, Thaler HT, Gangi MD, Hadju SI. Immunoperoxidase staining of cervicovaginal smears after radiotherapy. Acta Cytol. 1992; 36(3):305-9.

49. Masubuchi K, Kubo H, Tenjin Y, Ono M, Yamazaki M. Follow-up studies by cytology on cancer of the cervix uterine after treatment. Acta Cytol. 1969; 13(6):313-26 